DOI https://doi.org/10.36059/978-966-397-242-8-8

Тараненко О. Г., кандидат філологічних наук, доцент Східноукраӥнського национального університету імені Володимира Даля

м. Сєвєродонецьк

\title{
ОСОБЛИВОСТІ СЕМАНТИКО-ПРАГМАТИЧНОГО АСПЕКТУ ЛЕКСЕМИ «БІЗНЕС» В УКРАЇНСЬКІЙ ТА АНГЛІЙСЬКІЙ МОВАХ. ПОРІВНЯЛЬНИЙ АСПЕКТ
}

Анотація. У пропонованій розвідиі зосереджено увагу на аналізі застосування семантико-прагматичної складової лексеми «бізнес» в українській та англійській мовних реаліях у порівняльному аспекті. Дослідження проводилось на лексичному та фразеологічному мовних рівнях, де на останньому емотивно-прагматичний аспект був представлений у розгорнутому вигляді. Матеріалом для дослідження слугували тлумачні та фразеологічні словники української та англійської мов. Також проведено порівняльний аналіз лексеми «бізнес» в українській та англійській мовних реаліях. Вищеозначені мови відносяться до різносистемних, тому дослідження семних компонентів було плідним та принесло цікаві лінгвістичні результати, які можна використовувати для написання рекламних та СEО-текстів, що мають чітку структуру, та для якої аналіз семної складової $\epsilon$ важливим елементом. Структура ефективного рекламного тексту завжди пропонує перш за все викликання певної позитивної емоції, а вже потім йде безпосередньо продаж товару чи послуги, тому важливість вивчення саме емотивного компоненту у цьому аспекті $\epsilon$ надзвичайно важливою. Дослідження надає можливість для написання креативних текстів як для україномовної, так й для англомовної цільової аудиторії, зважаючи на тотожність та різницю у сприйнятті даної лексеми у представників цих двох культур, враховуючи як денотативний, так й конотативний компоненти лексичного значення. 


\section{Вступ}

Сучасна парадигма знань вимагає від науковців проводити дослідження у русі модернізації та практичної імплементації отриманих результатів майже в усіх життєвих сферах. Це великою мірою стосується й лінгвістичних студій. Значний прогрес у сферах реклами, маркетингу, двобічного перекладу ставить нові вимоги для досліджень та вказує нові вектори та напрямки у відомих лінгвістичних царинах, як-от семантиці, прагматиці, психолінгвістиці та багатьох інших. Зазначені тенденції розвиваються як у вітчизняній науці, так й в закордонній, що прогнозовано $\epsilon$ результатом глобалізації. В якості яскравого прикладу зазначим, що слово (лексема) у широкому сенсі постає як центровий рушій побудови рекламних кампаній та отримання практичних результатів своєї діяльності. Для більш ефективної побудови текстів, що продають, використовуються семантикопрагматичний підхід для розробки правильної стратегії та досягнення максимального результату в найкоротший термін. Для отримання швидких та ефективних результатів необхідні знання 3 семантики та прагматики та їх грамотного застосування.

Аналіз семантичного поля - це один 3 найпродуктивніших шляхів для побудови результативних запитів у мережі Інтернет та просування сайтів, а урахування прагматичних аспектів допоможе у правильній спосіб побудувати рекламний текст. У даній розвідці пропонуємо зосередитись на дослідженні семантико-прагматичних особливостей лексеми «бізнес» в українській та англійській мовах на двох мовник рівнях - лексичному та фразеологічному для отримання практичних результатів на прикладі широко вживаного терміну як в англійській, так й в українських мовник реаліях.

\section{Семантико-прагматичний аналіз лексеми «бізнес» на лексичному рівні}

Говорячи про семантичний аналіз лексеми, треба зазначити, що семантика як вчення про знаки та їх концептуальну реалізацію відносно нове. У 60-70ті роки ХХ-го століття теорія значення Л. Блумфілда дала поштовх для розвитку семантики як лінгвістичної галузі. Семантикою цікавились такі вчені як

I. Білодід, А. Вежбицька, „M. Жовтобрюх, Дж. Лакофф, О. Селіванова, 
Ю. Степанов, та багато інших [2; 11]; деякі з них ототожнювали семантичні студії 3 вивченням та аналізом концептів (лінгвістичний аспект). Сюди можна віднести С. Жаботинську, В. Карасика, И. Стерніна, В. Кононенка та багатьох інших [2; 11]. Прагматика також відносно нова галузь у лінгвістичному сенсі, яку розробили Ч. Морріс та Ч. Пірс, вона вивчає поведінку знаків у комунікативних процесах, активно розвивається на сучасному етапі, а її результати використовуються для втілення у життя різноманітних технік для ефективного впливу на людську свідомість, що широко використовуються насамперед у політичному та рекламному дискурсі.

У цій частині хочемо зосередитись на дослідженні семантичного поля лексеми «бізнес» в українській та англійській мовах на матеріалі сучасних тлумачних, двомовних та автентичних словників обох мов.

У сьогоденних ділових реаліях лексема «бізнес» одна за найуживаніших, але для ефективного аналізу треба розробити чітку стратегію визначення основних компонентів цієї лексеми у структуру як української, так й англійської мов. Природно, що лексема «бізнес» для української мови не $є$ рідною - це запозичення саме з англійських мови, тому це вже надає специфічних рис для «бізнесу» в українських мовник реаліях. Семантичне поле доречно досліджувати насамперед через призму словників, де зафіксовано найбільш вживані елементи 3 необхідними позначками та визначення семантичної складової.

Слово «бізнес» набуло активного вживання приблизно 3 останньої третини XX-го століття та набувало дещо негативне значення, бо у колишньому СРСР приватної власності офіційно не було, а людина, що мала підприємниці здібності, не мала можливостей їх реалізувати через політичну ситуацію. «Словник української мови», виданий якраз у зазначений період часу, фіксує таке значення лексеми: Бізнес - чол., розм. Комерційна, біржова чи підприємницька діяльність як джерело наживи у капіталістичному світі [12, с. 179]. Тобто, у позначці розм., що відображає емотивну забарвленість, ми стикаємось 3 негативною конотацією, вираженою мовним штампом «джерело наживи». У свідомість людини того часу вкладалось, що бізнес - це погано, не зовсім зрозуміла, у багатьох випадках небезпечна та не притаманна радянський людини діяльність. Зазначимо, що лексему «бізнес» в концептуальному аспекті досліджував И. Крюков на матеріалі 
мовного корпусу сучасної російської мови [7, с. 267]. У своєму аналізі він наголошував, що «бізнес» увійшов до вживання приблизно у 80-ті рокі минулого століття; в українських лексикографічних джерелах нами теж знайдено підтвердження цій думці. Але 3 90-х років XX-го століття часи стрімко змінились завдяки політичним подіям, західний вектор активно розвивався, тому бізнес припинив бути чимсь «негативним», багато людей навпаки зацікавились розвитком приватного підприємництва.

У словниках це відбилось новим значеннями та забарвленням цієї лексеми. Наприклад, у «Тлумачному словнику української мови» В. Бусела подається така дефініція: Бізнес - чол. економічна, комерційна, біржова або підприємницька діяльність, спрямована на отримання прибутку [3, с. 80]. Ми бачимо констатацію головних напрямків розвитку бізнесу, а далі словникова стаття подає звороти, що уточнюють значення лексеми, а також семантично розширюють іï: Бізнес-операція - сукупність дій, процедур, що складають зміст одного акту бізнес-діяльності; угода; Бізнес-клас місця підвищеної комфортності у літаку; Бізнес-план - програма для підприємництва, бізнес-операції [3, с. 80]. Природно, що із розвитком бізнесу в нашому житті розвинулось багато різновидів цієї діяльності, що знайшло відбиток у словнику, де конкретизовано види бізнесу та пояснено основні напрями цієї діяльності: бізнесцентр - місце організації ділової діяльності, надання послуг бізнесменам; венчурний бізнес - підприємницька діяльність невеликих творчих груп новаторів, які отримують дохід завдяки впровадженню нових ризикових винаходів; інформаційний бізнес комерційна діяльність $з$ метою отримання доходу в сфері інформаційного обслуговування [3, с. 80]. Малий бізнес - економічна діяльність, що дає прибуток на малих та середніх підприємствах; технологічний бізнес - різновид підприємницької діяльності у сфері нових технологій [3, с. 80$]$.

Все це характеризує значне розширення семантичного поля лексеми, що показує її зростаючу значущість у сучасному житті. Цікавим виявляється також й гендерний аспект: у словнику подано не тільки дериват бізнесмен як великий ділок, комерсант, підприємець, людна, що робить вигідну справу, але й бізнес-леді як жінка, що займається бізнесом [3, с. 80]. Виявляється, що комерція це не суто чоловіча галузь, існують жінки, що успішно займаються 
бізнесом та активно його будують у багатьох царинах. Це також $€$ частиною глобалізації та доступу до рівних можливостей.

Розглянемо дані ще декількох тлумачних словників. У тлумачному словнику В. Дубічинського вказано, що бізнес [англ. Business «справа»]. економічна, комерційна, біржова, або підприємницька діяльність, спрямована на отримання прибутку, а бізнесмен - це комерсант, підприємещь $i$ m. ін., людина, яка займається бізнесом [13, с. 59]. Це визначення здається тотожним вищеозначеному, але немає гендерного компоненту бізнес-леді. В той же час подається, що бізнес - це запозичена за англійської мови лексема та розшифровується дефініція. Подібно описують цю лексему й автори тлумачних словників Л. Ващенко, А. Яковлева, 0. Сліпушко та А. Івченко, де бізнес - підприємнищька діяльність, яка дає прибуток [14, с. 35]; бізнес - економічна, комерційна, біржова, або підприємницька діяльність, спрямована на отримання прибутку [18, с. 63]; бізнес - торгівельна, підприємницька, біржова діяльність, спрямована на одержання прибутків [5, с. 30; 15, с. 75]. Більшість словників також зафіксували лексему «бізнесмен», що описує того, хто займається бізнесом [5, с. 30], чи є підприємцем, комерсантом, що працює в певній сфері економічної діяльності, з метою прибутку чи іншого зиску [15, с. 75].

Практично в усіх досліджуваних словниках вказано, що це запозичена лексема, це означає, що їх потрібен певний час для повного адаптування в українській мові, тому часто лексема «бізнес» замінюється семантично близьким та у деяких випадках синонімічною лексемою «справа». Це підтверджується даними з англо-українського словника економічних термінів С. Єрмоленка та В.Перебийноса: справа (підприємство) - business, company, enterprise, supervision, going concern, venture [16, с. 459]; business - справа, діло, заняття [16, с. 29]. Звернімося до даних спеціалізованих словників економічних термінів, що також дають дефініцію лексемі «бізнес». У словнику економічних термінів за редакцією О. Тараненка уточнено: бізнес - великий бізнес, дрібний бізнес, бізнесмен [10, с. 13], а також окремо визначено лексему біржа - товарна, товарно-сировинна, фондова [10, с. 13], що свідчить про розширення семантичного поля та зв'язок 3 англійською дефініцією лексеми бізнес.

У словнику С. Єрмоленка спостерігаємо семантичне розширення такими дефініціями, що $є$ складовими бізнесу з перекладом: бізнесплан (business plan), біржова ціна (exchange price, quoted price), 
біржове котирування(stock exchange quotation), біржовий брокер (stock broker, exchange broker, trader, stock exchange dealer) біржовий крах (marker crash), біржовий курс (stock exchange price), біржовий трейдер (floor trader), біржові індекси (stock indices) біржові операції 3 облігаціями (bond trading) [16, с. 38]. Розкрито дефініції спеціалізованої лексики, що належить до економічної сфери та $\epsilon$ розповсюдженою у певних колах. Також зафіксовано представників доволі нових бізнес-професій, як-от біржовий брокер, трейдер та інші.

у сучасній парадигмі тотального користування мережею Інтернет дані професії трансформувались у трейдерів криптовалют, інтернет-трафіка ті ін. В автора наступного англо-українського словника знаходимо такі цікаві елементи: діловий лист (a business letter), робочі години (business hours) [16, с. 29]. Як бачимо, у перекладі на українську однаково частотно застосовуються як лексема «бізнес», так й «справа».

У словнику М. Зубкова business - це діло, постійне заняття, бізнес, а також професія, обов'язок, право; торговельне підприємство, фірма; комерційна діяльність та вигідна угода [4, с. 1331]. Цікава й лексема Business like, що перекладене як діловий, практичний, точний; зібраний, ретельний, старанний, акуратний [4, с. 1331]. Уточнено також дефініцію бізнесмен - (Businessman) як ділова людна, комерсант; ділок, бізнесмен; Business-manager управлінець, комериійний директор, завідувач комерційної частини [4, с. 1331]. Також зауважено нові професію, по'вязані 3 бізнес-сферою: менеджер, комерційний директор, завідувач комерційної частини.

Виходячи з проаналізованого вище, надаємо таку семну структуру лексеми «бізнес» на українському мовному матеріалі: архісема «бізнес як діло, спосіб отримання прибутку, зиску». Змістовні семи: «бізнес як суспільство ділових людей» ; «бізнес як підприємство»; «біржа як змістовна частина бізнесу» біржові операції та професії»; «бізнес як комерційна діяльність»; «бізнес-галузі у різних сферах життєдіяльності»; «бізнес як справа у широкому сенсі». Загалом, лексема бізнес має нейтрально-позитивне значення у проаналізованих прикладах. Також існує семна гендерна ознака «бізнесмен», «бізнес-леді», «бізнесвумен». 3 негативним забарвленням $\epsilon$ тільки елементи: «не втручатись у чужі справи»,

Аналізуючи дані автентичних англомовних словників, зазначимо, що в англійській мові лексема «бізнес» займає важливе 
місце та володіє великою кількістю сем через значну розгалуженість значень, які ми наразі й розглядатимемо.

В Оксфордському тлумачному словнику подається таке значення лексеми: business is the activity of making, buying, selling or supplying goods or services for money (бізнес - це діяльність пов'язана з покупкою, спродажем, забезпеченням, виробництвом товарів чи послуг за грошову винагороду) [22]. Надаємо декілька прикладів: it's been a pleasure to do business with you (з вами приємно вести справи(бізнес); there will be some changes in the way we conduct business (відбуватимуться деякі зміни у тому, як ми ведемо бізнес); when he left school he went into business with his brother (коли він покинув школу, він зайнявся сімейним бізнесом з братом) [22]. Також, як в деяких вищезазначених українських джерелах, надається градація бізнесу, його різновиди: The music/entertainment/insurance/ food/banking business (музичний, розважальний, страховий, харчовий, банківський бізнес); business opportunities ventures/interest/sector/cycle/world

(бізнес-можливості, підприємство, інтереси, сектор, цикл, світ); business partner, business community, core business (the main thing that Business does) (бізнеспартнер, суспільство, головна сутність бізнес-діяльності) [22].

Ці приклади свідчать про розгалужену систему взаємопов'язаних сем у структуру лексеми «business», де головними виступають «бізнес як комерційна діяльність»; «бізнес як справа»; «бізнес як спосіб життя та частина особливого суспільства», «бізнес як сімейна справа». Також представлені такі визначення бізнесу: business as a work that is a part of your job; an amount of work done by the company; the rate or quality of this work («бізнес як робота, їі частина»; «робота на компанію»; «якість проведеної роботи»).

Можна констатувати, що у свідомості англомовних лексема «business» тісно пов'язана не тільки з лексемою «справа» (affair, deed, action), але й 3 «робота» (work, job). Декілька прикладів, щоб проілюструвати цю думку: business is blooming (бізнес процвітає); business was bad; I found the whole business very depressing (справи йдуть погано); To be good for business (підходити для бізнесу); uncertainly is bad for Business (невизначеність погана для бізнесу); we are grateful for your business (ми вам вдячні за вдале ведення бізнесу) [22].

Бізнесом у розумінні англомовних носіїв часто постає не тільки велике комерційне підприємство, але й маленька крамниця, невеликий сімейний бізнес (a commercial organization such as a company, 
shop or factory; she works in the family business); безпосереднє керівництво бізнесом, його розвиток та розширення (to run/start a business; to grow/expand/build a business); річ чи справа, за яку несуть відповідальність чи те, що мають обговорити, матимуть справу (Something that a particular person or organization is responsible for; important matters that need to be dealt with or discussed ) [22]. Приклади цього значення: I shall make it my business to find out who is responsible (я знайду відповідального самотужки); The main business of the meeting (головна ціль зустрічі). Цікавим $\epsilon$ зв'язок з негативною емотивною забарвленістю у прикладах It is no a business of hers who I invite to the party (не іï справа, кого я запрошуватиму на вечірку); Keер уоur nose out of my business (не пхай носа у мої справи), де використано саме лексему «business», а не синонімічні «саse», «affair». Синонімічні вирази представлено й українських прикладах, наданих у дослідженні.

У тлумачному словнику М. Вебстер зафіксовано цікаве значення «business» як a damaging assault («загроза фізичного насильства»), що представлене суто в англомовному дискурсі [23]. Той же словник М. Вебстер надає таке визначення лексеми «business» as the activity of making, buying, selling goods or providing services in exchange for money 3 синонімами сотmerce (комерція), trade (торгівля) [23]. Значення, подані у словниковій статті, пов'язано насамперед з комерційною та торгівельною спрямованістю та діяльністю: An amount of activity that is done by a store, company, factory (діяльність, проведена магазином, компанією, фабрикою); A usual commercial or mercantile activity engaged in as a means of livelihood (trade, line in business)(рутинна комерційна діяльність, що забезпечує засоби до існування, як-от торгівля, лінія у бізнесі); A commercial or sometimes industrial enterprise (комерційне чи виробниче підприємство); Dealings or transactions, especially in economics (торгівля та трансакції в економічній сфері) [23]. Ще одним значенням виступає розуміння бізнесу як роботи та конкретного завдання (Work as a part of your job, an immediate task or objective); конкретна царина (A particular field of endeavor); соціальної ролі (Patronage, nature, Role, function), Наявне також значення бізнес як справа (Affair, matter) [23]. Це перекликається із значеннями, поданими у Тлумачному словнику англійської мови [19]: calling, vocation (покликання), employment (працевлаштування), commerce (комерція), traffic (рух), trade (торгівля), company (компанія), firm (фірма). Згідно даних цього словника, business - an occupation, profession or trade (робота, освіта, професія або торгівля); a purchase or 
sale of goods in an attempt to make profit (придбання чи продаж товарів у спробі отримати прибуток) [19].

Всі ці значення корелюють 3 наведеними вище англомовними джерелами. Є додаткові значення: volume of trade, patronage («обсяг торгівлі, меценатство»); something of which a person is rightfully concerned (справа, через яку відчувають справедливу занепокоєність); affair, project, assignment, task (chore = piece of business) (справа, проект, завдання, рутинний обов'язок). Тобто, у деяких значеннях навіть виконування домашніх обов'язків може мати назву «бізнес»: household chore = business.

Цікаве значення «меценатство» «патронат» у контексті бізнесу. У театральному середовищі $\epsilon$ таке значення ««business»: Theater: $a$ movement or gesture, especially a minor one, used by an actor to give expressiveness, drama, detail, to a scene, to portray a character (рух чи жест, особливо печальний, що використовується актором для експресивності, драматичності сцени та характеристики персонажу) [19]. Останній приклад надзвичайно цікавий та має специфічну спрямованість, для вузького кола (театр та його функціонування). Відомо, що театральна діяльність - це один 3 важливих наріжних каменів британської культурної традиції, тому семне значення лексеми «бізнес» у даному контексті $\epsilon$ значущим та цікавим; відображає специфіку використання лексеми та іiі багатовекторність. В українській мовній картині такого значення лексеми не спостерігається.

Інші елементи семантичної структури доволі прогнозовані: business is a building or site where the commercial work is carried on, as a factory, store or office place of work (приміщення, де проводиться комерційна діяльність, як-от фабрика, магазин або офіс, місце роботи); a person, partnership or corporation engaged in commerce, manufacturing or services profit-seeking enterprise or concern (людина, партнерство чи корпорація залучена у комерцію, виробництво чи турбота про це); containing, suitable for, welcoming or commerce (те, що підходить для торгівлі та комерційної діяльності) New York is a good business town. (Нью-Йорк - це місто сприятливе для ведення бізнесу) [19].

В англомовному ресурсі для ділових людей Investopedia y визначенні бізнесу надано цікаву градацію: Businesses can be forprofit entities or can be non-profit organizations that operate to fulfill a charitable mission or further a social cause [20]. Семний елемент «бізнес як благодійність» перекликається із визначенням у тлумачному 
словнику [19], де зафіксовано значення «меценатство». Для представників англомовної спільності бізнес таким чином виступає як не тільки те, на чому можна зробити гроші та отримати прибуток, але й можливість допомогти іншим через неприбуткові спілки чи організації. У ресурсі подано такі два визначення бізнесу: this term refers to two different meanings; the first refers to an entity that operates for commercial, industrial or professional reasons....the second definition of business refers to all of the activities involve with the sale and purchase of goods and services (термін відображає два різних значення: перше відноситься до організацій, що працюють 3 комерцією, виробництвом та професійниками, а друге визначення відноситься до справ, пов'язаних з торгівлею, набуттям товарів та послуг) [19].

Тому, два головних моменти - це бізнес-суспільства різного розміру, а інше - це операції, які призводять до накопичення та надбання капіталу, прибутку. Зазначимо, які саме семні компоненти формують структуру «бізнесу» в англійській мові на основі проведеного аналізу: «бізнес як підприємництво»; «бізнес як своя (сімейна) справа»; «бізнес як джерело прибутку»; «бізнес як торгівля»; «бізнес як благодійність» (таке значення відсутнє в українських джерелах); «бізнес як покликання»; «бізнес як комерція»; специфічний компонент «бізнес як театральний прийом». Також семантично близьким $\epsilon$ дериват «бізнесмен», тобто, людина, що знає, як заробити гроші за збільшити прибуток. Цікаво, що на відміну від українських, в англомовних словниках не зафіксовано гендерної спрямованості бізнесу (лексему business woman не зафіксовано). Це може бути пов'язане із слабкою вираженістю граматичної категорії роду в англійській мові на відміну від української. Маємо констатувати, що в англомовних словникових ресурсах представлено набагато більш розгалужену семну структуру лексеми «бізнес», що пов'язано з більш давніми традиціями підприємництва у представників англомовних культур. Для української мовної спільноти цей термін знаходиться в активній стадії розвинення, тому багато значень (семних компонентів) замінюються семантично близькою лексемою «справа», особливо при перекладі. 


\section{Семантико-прагматичний аналіз лексеми «бізнес» на фразеологічному рівні}

Фразеологічний фонд будь-якої мови завжди яскраво та емоційно забарвлено відображає основні аспекти культурного коду нації. Тому дослідження $Ф 0 €$ завжди актуальними та значущими. Це зазвичай перевірені часом словесні вирази, що чітко корелюють 3 ментальною структурою нації, відображають іï значущі риси та головні концептуальні маніфестації.

Фразеологія як галузь філологічного знання має свої витоки 3 вивчення сталих виразів, зазвичай, народної творчості, та тих, що виникли у процесі життя та еволюції певної нації. Природно, що фразеологічна наука тісним чином пов'язана із семантикою. Тому ми беремо ФО як плідний матеріал для нашого дослідження. Проблемою дослідження ФО займались такі вчені як О. Кунін,

В. Виноградов, К. Мізін, В. Шанський та інші [11]. Дослідження семантичної структури лексеми «бізнес» базуватиметься саме на аналізі фразеологічних одиниць (ФО) з фразеологічних словників української мови для дослідження прагматичної функції та для виявлення емотивної забарвленості семних елементів у складі досліджуваної лексеми (семеми). Емотивний аспект надзвичайно важливий для ефективного використання лексеми та її семних складових у рекламних кампаніях та текстах. До того ж, ФО яскраво демонструють прагматичні аспекти, коли їх вживано задля конкретної мети та досягнення комунікативної цілі. Тобто, 3 доцільним та доречним використанням ФО можна задіювати саме емоцію, що ефективно впливає на підсвідомість. Перейдемо до безпосереднього дослідження ФО, що емотивно забарвлюють семантичне поле «бізнесу» в українській мовній свідомості, враховуючи той факт, що сама лексема відносно нова, тому у більшості випадків замінялась лексемою «справа».

Отже, аналізуючи ФО методом суцільної вибірки з залученням автентичних фразеологічних словників, наголосимо, що в цілому, семантична структура даних ФО відрізняється високою емотивною забарвленістю, бінарними опозиціями «добре-погано» та виявляє основні якості, притаманні людини, що займається бізнесом (справою) в українській мовній свідомості.

Ми зосередились на тих якостях, що притаманні діловій людині для будування та подальшого розвитку успішного бізнесу. Перша сема, яку ми розглянемо, буде «лідерство» як найбільш вживана та 
широко представлена у ФО. Лідерство - не наріжний камень будьякої вдалої справи, що просуває бізнес та робіить його надуспішним, а керівника - людиною великих фінансових можливостей. Це знайшло відображення у таких Ф0: господар становища [8, с. 45]; підніматись на космічну висоту [8 , с. 142]; показати себе [ 8, с. 148]. просунути справу [8, с. 160]. Справжній лідер завжди чітко знає, куди йти для успіху, завжди має план дій. Тому конотація цих ФО схвальна, позитивна, з відтінком поваги та трохи заздрощів щодо тих, хто спромігся досягти космічних висот у бізнесі. Активність - це ще одна важлива якість лідера, це підтверджується наступними Фо: бути на коні [6 , с. 29]; грати першу скрипку [6, с. 131] ; вести за собою [8, с. 28]; мати вплив [8, с. 102]; передова позиція [8, с. 138]; ходити в передовиках [8,с. 524]. Останню Ф0 відрізняє дещо застаріле значення, бо у передовиках виробництва зазвичай ходили успішні люди при радянській владі, вірогідно, що через це зараз вживання цього ФО на сучасному етапі достатньою мірою обмежене. Також лідера відрізняє від інших здатність та бажання брати на себе відповідальність: брати на себе [17, с. 52]; брати в свої руки [17, с. 53]; відповідати головою [8,с. 37]. Конотація у цих випадках схвальна та позитивна, з емоцією поваги та захоплення.

Не так все очевидно із конотацією таких ФО, як арена боротьби [8, с. 16]; вступати в права [17, с. 158]; набирати силу [8, с. 106]; мати перевагу [8, с. 102], де лідерство має ознаки «йти по головах», «жорстка конкуренція». Звісно, що у бізнесі, насамперед великому, конкуренція висока; інколи люди вдаються до різних, підчас жорстких заходів для отримання першості. Тому бізнес - це галузь, де боротьба ніколи не припиняється, тобто, конотація не є повністю позитивною, з відтінком тривожності та страху.

Важливою якістю лідера $\epsilon$ самобутність, здатність знаходити нестандартні рішення та втілювати їх у життя: мати своє стежку, шлях [17, с. 475], а також володіти міцною нервовою системою та психічною витривалістю, що відображено у ФО володіти собою [17, с. 143]. Ці елементи безперечно, мають позитивну, схвальну конотацію. Яскравою також постає сема «великий дохід». Як зазначено вище, у свідомості пересічної людини бізнесмен - це насамперед людина великих фінансових можливостей. Це знайшло своє відображення у наступних Ф0: ворочати мільйонами [6, с. 101]; гребти гроші лопатою [17, с. 196]; кишеня не сходиться [17, с. 374]; повна чаша (гаманещь) [6, с. 412-413]; де відчутна складна конотація 
заздрощів та водночас захоплення, бо бути заможною людиною - це мрія великої кількості людей, але, звісно, не всі ладні важко працювати, тому конотація заздрощів доволі відчутна. Вона посилюється у наступних ФО: гаманець набитий $[17$, с. 168]; набивати кишені [17, с. 517], де негативізм щодо людей з грошима зростає.

Водночас, кожен розсудливий бізнесмен знає про потребу економити для розвитку справи: копійка в кишеню пливе [17, с. 389], тобто, й не дуже великий дохід - це все одне гроші, які можна пустити в оберт. Конотація схвальна, ближче до позитивної, на відміну від попередніх ФО.

Ще однією з цікавих та яскраво виражених сем $\epsilon$ ентузіазм, що $€$ невід'ємною якістю успішного ділка, бізнесмена. Конотація позитивна та схвальна, це можна проілюструвати наступними ФО: аж горить під руками [6, с. 3 ]; аж кипить у руках [6, с. 8 ]; горить у руках [8, с. 45]; брати в роботу [17, с. 742]; всіма силами [17, с. 168]. Людина, яка працює з «вогником», завжди матиме переваги перед тими, хто просто «відбуває час» на роботі. Ентузіасти нерідко готови ризикувати та починати з нуля [6, с. 508], що оцінюється схвально у людській свідомості. Схвально та в цілому позитивно оцінюється й намагання людини жити своєю працею [8, с. 62]; займатись справою життя [17, с. 853]. Зовсім не так у людській свідомості оцінюється надмірний ентузіазм, бажання вислужитись, що слугує ознакою лицемірства: аж із шкури пнутися [6, с. 250 ], де навіть слово «шкура» має різке негативне забарвлення. Тому можна сказати, що в цілому ентузіазм лишається загалом позитивною якістю й необхідною складовою для побудови успішного бізнесу.

Коли у людини багато зароблених грошей, $є$ своя справа, що приносить великий дохід, то для нього/неї велике значення має статусність, положення у суспільстві, набуте у багатьох випадках, завдяки фінансовій складовій. Це ілюструють такі ФО: багато важити ,мати велике значення [8, с. 16]; важлива, знатна птиця [6, с. 345; 8, с. 26]; високої проби, високо літати, вищої марки [6, с. 64-65; 8, с. 33]. Всі ці Ф0 відображають конотацію поваги, пошани, позитивне забарвлення. Негативне, іронічне забарвлення щодо людей, які занадто пишаються своїм фінансовим положенням, відображають ФО велика пані [6 , с. 344]; велика риба [6, с. 34]; велике цабе [6, с. 347;8, с. 27]. Останній варіант є трохи застарілим, вживаним переважно старшим поколінням. 
Ознаки статусності, елітарності бізнесу відображають ФО бути на висоті положення [8, с. 25]; витримувати марку [8, с. 33]; справа великої ваги [8, с. 177], мати репутацію [8, с. 103], на рівні вищих світових стандартів [8, с. 114], де конотація переважно позитивна, з повагою.

Дуже цікавою виявляється бінарна опозиція сем «удача-невдача в бізнесі». Удачу в бізнесі з позитивною конотацію відображено у наступних Ф0: увінчатись успіхом [8, с. 191]; мати успіхи, великі успіхи [8, с.103]; акції підвищуються [6, с. 3; 8, с. 14; 17, с. 637]. Також широко представлено удачу як подарунок долі, фортуни: колесо фортуни [8, с. 92]; бути у виграші [8, с. 25]; виграти козиря, справу [6, с. 47-48]; попасти у масть [6, с. 421] справа, діло вигоріло $[17$, с. 245]. Удача у будь-якій справі - це невід'ємний елемент, тому для бізнеса, де завжди існує вагома доля ризику, удача $\epsilon$ суто позитивним та важливим моментом.

Повністю протилежне, негативне значення з відтінком жалю набувають Ф0, що відображають невдачу: акції падають [6, с. 11; 8, с.14]; програти справу [6, с. 48]; ламати справу [6 , с. 96]; справа не клеїться, не ладиться [8, с. 177], пуста справа [8, с. 161]. Невдача може спіткати будь-кого, тому конотація застережлива, 3 відтінком суму. Семантично близькими виступають ФО, що відображають сильну та несподівану невдачу: вибивати з сідла $[6$, c. 40]; вибитися з колії [6, с. 41]. Для бізнесу несподівані ризики завжди руйнівні, тому підприємці будь-як намагаються їх уникнути чи мінімізувати.

Ще одна важлива бінарна опозиція ц структурі семантичного поля «бізнесу», це «чесність»-«нечесність», де позитивною конотацією володіє «чесність», а «нечесність» забарвлена суто негативно. Вагомим аргументом для ведення успішного бізнесу $\epsilon$ чесність при його розвитку, це відбивається у численних прикладах, як-от: давати гарантію [8, с. 47]; сказано-зроблено [8, с. 172]; грати 3 відкритими картами [8, с. 46]. У прикладах проілюстровано емоцію поваги та схвальності щодо бізнесменів, які грають чесно, чесно ведуть свої ділові справи. Важливим моментом $€$ непохитність слова ділової людини, їі порядність у виконанні узятих на себе обов'язків: слова свого не зламати [17, с. 415]; лишатись вірним своєму слову [8, с. 98]; давати слово [8, с. 48]; бути господарем (хазяїном) свого слова [8, с. 25]. Це викликає суто позитивні емоції шани щодо таких підприємців та бізнесменів. 
Осторонь стоїть ФО вірити на слово [8, с. 37], де підіймається питання довіри, яке у деяких випадках може бути порушене, тому конотація застережлива, до того, є ФО вийти з довіри [8, с. 30], що підкреслює конотацію побоювання через брак довіри. Повністю негативним, зневажливим лишається в людській свідомості відношення до семи «нечесність»: обкрутити дільце [17, с. 247]; обтяпати дільце [17, с. 568]; вийти сухим з води [6, с. 52]. Цікавим $\epsilon$ спостереження, що негативно забарвлених елементів значно менше, ніж позитивних, тому у людській свідомості відбивається, що тих, хто веде справи чесно, більше, ніж навпаки.

Досить суперечливою конотацією володіє така сема як «амбітність». Вона не дуже виражена у $Ф 0$, але $\epsilon$ цікаві приклади, що ілюструють емотивну складову «амбітності». У позитивному сенсі можна розглядати ФО піднятись на вищий шабель, ступінь [17, с. 638]; іти вгору, високо піти [17, с. 353]; діло не чекає [17, с. 245], де амбітність показано як прагнення до висот у своєму ділі, що характерне для успішних підприємців на бізнесменів. Водночас, надмірна амбітність викликає негативні емоції, презирливе ставлення, як-то ФО дертися вгору [17, с. 233], коли людина за своїми амбіціями забуває про важливі людські якості. У цілому, здорові амбіції - це зазвичай рушій бізнесу, але завжди присутня й моральна складова шляху на верхівку можливої кар'єри, тобто щоб не було ситуації «піти по головах».

Однією з важливих складових є семний компонент «досвід», який необхідний для успішного розвитку бізнеса та управлінських процесів у ньому. Людна, яка має досвід, завжди може бачити далеко [6, с. 14], бути у курсі $[8$, с. 25], ділом доводити [8, с. 54] свою компетентність, що має позитивне емотивне забарвлення, а також конотація схвальності, поваги та захоплення. Трохи інший емотивний компонент у таких Ф0: бите око [8, с. 19]; битий жак [6, с. 21]; битий жубк [6, с. 185], де можна прослідкувати емоцію негативного характеру; досвіду, набутого методом не зовсім успішних спроб та намагань, де доводилось принаймні залишитись при своїх інтересах [8, с.68], без очікуваного прибутку. Така людська якість як корисливість ні в кого не викликає позитивних емоцій, тому приклад - це ФО, що відображають цю не саму приємну якість: здобувати користь [8, с. 71], ловити рибку [17, с. 447]; для своєї вигоди [8, с. 55]. Однак ця сема має певне значення для 
характеристики людини-бізнесмена, бо більшість 3 них користуються бажанням заробити.

До бажання заробітку прямо відноситься наступна сема «працьовитість», що загалом має позитивне емоційне забарвлення. Для бізнесмена це одне 3 найважливіших якостей для спіху. Проілюструємо це прикладами відповідних ФО: докладати своїх рук [17, с. 259]; бути при ділі [8, с. 25]; доходити до діла [17 с. 267]. Водночас, у людській свідомості праця пов'язана 3 тяжкими зусиллями, що мають негативне забарвлення, відчуття суму та туги. Приклади ФО: добути своїм горбом [17, с. 254]; гірко заробиш, солодко з'їси [8, с. 42]; підставляти шию в ярмо[6, с. 407; 8, с. 13]; гнути горба, спину, шию [6, с.119-120]. Елемент бінарної опозиції сема «лінощі» - представлена небагатьма прикладами, бо для ділових людей це не притаманна якість, яка тільки заважатиме на шляху до успіху: де багато слів, там мало діла [8, с. 50]; бити байди [6, с. 133]; тяп-ляп [6, с. 124], спочивати на лаврах [17, с. 852]. Конотація вкрай негативна, осудлива.

Сема «авторитарність» представлена небагатьма прикладами, але зазвичай керівник бізнесу може бути занадто вимогливим, навіть жорстоким. Це знайшло відображення у наступних ФО: знімати стружку [6, с. 257]; не давати спуску [6, с. 354]; вичавлювати соки (олію) [8, с. 34]; гнути свою лінію [8, с. 42]; держати у своїй кишені [17, с. 227]. Конотація негативно забарвлена, з відтінком осуду та несприйняття. Цікавим а також необхідним для будь-якого бізнесмена $\epsilon$ здатність бути гнучким, здатним до діалогу, компромісам, готовим домовлятись. Тому сема «гнучкість» доволі широко виражена у ФО: доходити згоди [6, с. 259] загладжувати гострі кути [6, с. 190]; знаходити спільну мову [6, с. 229]; досягати взаємо порозуміння [ 6, с. 58]; іти в фарватері [8, с. 86]; обопільна згода [8, с. 132]. У цих прикладах конотація в цілому позитивно-нейтральна, чого не відбувається у наступних прикладах, де гнучкість вже перетворюється у хитрі те нечесні махінації: зробити гешефт [17, с. 346]; справа на мазі [8, с. 177]; стук-грюк, аби з рук [6, с. 262]. Конотація негативна, презирлива.

Насамкінець лишається така сема як «професіоналізм», без якої відкриття та розвиток справи просто неможливий. Безсумнівно, це одна 3 найзначущих елементів у структурі лексеми «бізнес». Конотація переважно позитивна, з емоціями поваги та захоплення. Продемонструємо це прикладами ФО: справа в надійних руках 
[8, с. 54]; мати своє стежку, шлях [17, с. 475]; держатися свого берега [17, с. 231]; довести ділом, до відома [17, с. 255]; тримати курс [8, с. 183]. Професіонал своєї справи завжди спроможний давати лад [17, с. 207]; дійти до суті справи [8, с. 58], говорити по суті [6, с. 370]; увійти в ритм [8, с. 203]; бути в курсі (справи) [6, с. 28]. Також він/вона може тверезо оцінити, чи варта справа заходу [6, с. 26]; справа йде гаразд [6, с. 177]; буде толк [6, с. 27] з ідеї, партнерства, нового співробітника та інших важливих питань. Конотація схвальна, позитивна. Цілком зрозуміло, що бути професіоналом своєї справи зробить бізнесмена насамперед конкурентоспроможним та дозволить бути на декілька кроків попереду конкурентів. Вартим особливої уваги $\epsilon$ різноманіття представлених у словниках речових штампів стосовно бізнес-сфери. Ці вислови дуже часто вживаються у сфері виробництва, діловій, та належать до кліше, якими активно користуються люди, шо належать до цієї галузі. Кліше використовуються як в усному мовленні, так й в письмовому, часто при складанні документів, належать до офіційно-ділового стилю, це так звані канцеляризми. Нерідко вони йдуть саме 3 такою позначкою у словниках. Розглянемо найпоширеніші 3 них. Багато 3 цих конструкцій відносяться до сфери виконання професійних обов'язків, як-от: вважати своїм обов'язком [8, с. 27]; виконувати службовий обов'язок [8, с. 30]; коло обов'язків [8, с. 92]. Зрозуміло, що для бізнесдіяльності надважливим $\epsilon$ визначення та розподіл обов'язків та чітке розуміння, хто на за який саме аспект діяльності себе персональну відповідальність. Це $є$ запорукою успіху ведення серйозної будь-якої справи. Також обов'язки мають відповідати посаді, яку займає працівник чи керівник; тобто є декілька кліше, що описують процес оформлення на працевлаштування: заступати на посаду [8, с. 70]; вступити на посаду [8, с. 41]. Коли людина має проходити навчання чи підвищення кваліфікації, то зазвичай вона проходить це без відриву від виробництва [8, с. 17], у свій вільний час, а якщо це нове місце працевлаштування, то поступово всі робочі моменти та обов'язки стають зрозумілими для виконання, тобто, входять в норму, колію, русло [6, с. 41-113]. Налагодження робочої атмосфери із здоровим мікрокліматом - це теж обов'язок керівника, що хоче досягти дійсно успішних результатів у своїй діяльності. Тільки таким чином можна заохотити людей працювати на максимум та робити вагомий внесок $[8$, с. 25] у розвиток бізнесу та 
виробництва та закласти фундамент $[8$, с. 67] свого невпинного фінансового розвитку, а також впроваджувати в ужиток [8, с. 40] ефективні короткострокові та довгострокові стратегії економічного розвитку. Ініціативність працівника, його ентузіазм та бажання розвиватись $\epsilon$ необхідними рисами для майбутнього роботодавця/керівника, що віддає належне [8, с. 35] таким якостям та визнає можливим [8, с. 29] фінансово заохочувати таких колег до співпраці. Відкрите питання [8, с. 37] може виникати через низку причин, але саме так визначається незавершена в силу різних причин ситуація, яка потребує швидкого та ефективного рішення у ділових питаннях чи робочих моментах. Важливим умінням $\epsilon$ досягнення взаємовигідного компромісу, коли можна дійти згоди [8, с. 51] по важливих питаннях, що постійно виникають у діловій сфері. Інколи таке може стосуватись фінансових зобов'язань, як, наприклад, давати у заставу [8, с. 48], де головним виступає питання взаємної довіри. Щодо використання даних кліше у рекламних текстах, то до цього треба підходити дуже виважено та не перевантажувати тексти реклами подібними штампами, які не викликатимуть сильної емотивного «занурювання» у текст в силу їх розповсюдженості та «банальності» використання у певних мовних ситуаціях.

\section{Висновки}

Підсумуємо, що семантичні та емотивно забарвлені характеристики ФО на українському мовному матеріалі розподіллено наступним чином: «лідерство», «високий дохід», бінарна опозиція «чесність/нечесність», бінарна опозиція «працьовитість/лінощі», «ентузіазм», «професіоналізм», «статусність», бінарна опозиція «удача/невдача», «корисливість», «амбітність», «досвід», «авторитарність».

Тепер перейдемо до аналізу ФО на основі аналізу англомовних автентичних джерел та виявимо головні складові «бізнесу» у розумінні пересічної англомовної людини з акцентом на емотивну складову. Розпочнемо само з лексеми «бізнес», як вже було зазначено, для української мовної свідомості це відносно нове явище, що 3 успіхом замінювалось лексемою «справа», то для представників англомовної спільності ця лексема функціонує 3 XV століття (що зафіксовано у словнику М. Вебстер). Можна сказати, що вона вже має сталі значення та Ф0, що відображають емотивне ставлення до бізнесу. В цілому, емотивні забарвленість виявляється 
позитивною та схвальною, але снують й деякі нюанси у ставленні до ділової активності.

Будь-яке втілення ділових якостей та розширення фінансової свободи через сумлінну працю - це характеризується схвально: $b e$ the business - (бути у ділі, добре на ньому розумітись); be in the business of doing something (розглядати якусь діяльність як головну частину твоїх обов'язків) [22]. Також присутній неформальний компонент у такому виразі, як to be in business (informal) (мати все для того, щоб розпочати щось негайно [22].

Звісно, що підприємницький талант, уміння розпочинати діло 3 нуля та бути в ньому успішним - це позитивна якість, що підкреслюється емоцією схвальності та захоплення та поваги, як у Ф0: big business (великий бізнес у компанія чи фінансових групах 3 сильним впливом чи продукт або діяльність, на яку люди витрачають багато грошей) [21]; business interests (бізнес-активи чи паї (акції) у компаніях) [21]; run a business (керувати бізнесом) [21;22] build up/develop / establish a Business (розпочати бізнес) [21; 22].

Цікавим $є$ приклад, коли придбають компанію чи починати нею керувати (take over a business ) [21] що не завжди має суто позитивне забарвлення, бо інколи це може траплятись у результаті нечесних махінацій. Нечесні махінації, брудний бізнес з негативною емотивною оцінкою відображено у ФО monkey business (погана чи нечесна поведінка) [21]. Ділові люди зазвичай не гають ані свого часу, ані часу інших людей. Ця позитивна риса відображена у ФО з позивною конотацією, бо це одне з головних правил успішного бізнесмена: get down to Business (давайте перейдемо до справ) [22]; неформальні like nobody's business (дуже швидко та успішно) [22]; mean business (серйозно відноситись, відповідати за свої дії ) [21]; a vialed business (бізнес, на якому знаються, що він має бути успішним) [21].

Цікаво, що багато ФО стосовно бізнес-активності мають позначку «неформально», тому бізнес - це те, що доволі часто обговорюється не тільки суто в ділових колах, але й серед пересічних осіб. Ф0 it's the business (спосіб неформально сказати, що щось йде чи працює дуже добре) [21]. Інколи виникають робочі питання, на які теж треба виділити додатковий час: any other business (інші бізнес-справи, які не були у порядку денному, але які треба обговорити) [22]. Ввічливо про таке повідомити партерів заздалегідь. Також серйозні бізнесмени ставляться відповідальна до розвитку та процвітання своєї справ: to drum up business 
(намагатись розвивати свою компанію через пошук нових клієнтів) [21]; apply for hire/trade/business (шукати клієнтів для бізнесу) [22]. Конотація схвальна та позитивна.

Стабільність та передбачуваність - це також одні з головних елементів успішного ведення справ, у ФО воно проілюстровано так: to go about your business (робити ті речі, що й зазвичай, у звичному ритмі) [22]; it is a business of somebody to do something (це справа когось робити щось) [21], and all that business (все теж саме) [21], навіть якщо справи не завжди йдуть успішно: business as usual (вираз, щоб підкреслити, що справи йдуть як звичайно незважаючи на деякі негаразди) [22]. Конотація позитивна, з елементами захоплення, бо для британського джентльмена завжди було принципових не виказувати надмірних емоцій та втілювати впевненість у собі. Це зараз стосується майже усієї бізнес-сфери, принаймні, більшості європейців. Надзвичайно важливо, щоб у бізнесі грали чесно та не ставили родинні чи дружні зв'язки вище, ніж справа: business is business (комерційні та фінансові інтереси ставитимуся вище, ніж людські відносини, бо діло понад усе) [22]; business before pleasure (спочатку справи, а потім- розваги) [22]. Емотивне забарвлення позитивне.

Природно, що на шляху до успіху має бути багато підводних каменів, перешкод та невдач, це відображено у наступних ФО: Business succeeds (займатись бізнесом непросто) [21]; out of business (вийти 3 діла через брак фінансів чи відсутності роботи) [22]; business collapse, fails (бізнес перестає функціонувати, невдача) [21]; have no business doing something (немає права робити щось) - уоu have no right to do something [22]. Конотація негативна, з відтінком досади та невдоволеності. В той же час, при можливості можна повернулись до бізнесу: be back in business (повертатись до справ) [21], де емоційне забарвлення вже схвальне, оптимістичне.

Цікаве неформальне, просякнуте емоціями значення ФО «не лізти у чужі справи». Для представників англосаксонської культури приватність та особисті межи $є$ головною цінністю для особистості, тому втручання у життя людини вважається неприпустимим: this is my business (це мої справи, не втручайся) [21]; mind your own business (не пхай носу в чужі справи) [22]; no business of yours personal concern (це тебе особисто не стосується) [23]. Можна сказати, що це порівнюється 3 втручанням у ведення справи, бо життя - наша найважливіша справа. 
Надзвичайно важливою складовою бізнесу є дохід (profit) - саме через великий заробіток люди й йдуть у бізнес. Цей елемент широко представлений у сталих виразах англійської мови: quick/big/huge/handsome/tidy/healthy profit (великий дохід); make a profit (отримати вигоду); generate/boost/maximize profit (зробити дохід максимальним) [21]. Також представлено декілька виразів професійної спрямованість net profit (дохід, отримані після оплати всіх податків) [21; 22]; gross profit (pre-tax) (дохід до оплати всіх податків) [21; 22]. Досягнення великих статків характеризується схвально та позитивно: profit soar/leap (зростання доходу значною мірою) [21]; profit margin (маржа, маржнальність) [23]. Але $\epsilon$ й негативне забарвлення, коли отримання прибутку пов'язане 3 корисними намірами: profit motive (корисливий мотив, причина) [23]. Інколи прибуток може бути зовсім незначним чи взагалі падає, що в принципі є природним у багатьох випадках: modest profit (невеликий дохід); profits are up/down (дохід росте чи падає); profit slump/plunge getting a large amount decreasing (падіння доходу) [21]. Конотація негативна, з відтінком жалю та стурбованості.

Семантично близько до попередньої постає й наступна сема «дохід» (income). Вона представлена не дуже широко, але $є$ змістовні та цікаві складові, як-от: a source of income (джерело прибутку) [21], що має позитивне значення, якщо дохід не низький, що підкреслює вираз income level/bracket (рівень доходу) [21]. Також наявна градація до отримання доходу: a joint income (дохід, що отримує дві та більше персон) [21]; discretionary income (дохід, що лишається після сплати всіх першочергових витрат, як-от, їжі, комунальних послуг) [23]; disposable income (дохід, що лишається після сплати податків для закриття першочергових витрат на кшталт їжі, комунальних послуг) [23]; household income (господарський дохід) [22]. Конотація здебільшого нейтральна.

В українській мовній культурі такої чіткої градації не виявлено. Негативно забарвлене значення має loss of income (втрата прибутку) [21], що цілком природно. 3 темою доходу на прибутку пов'язані саме «гроші» (money) як кінцевий результат будь-якого вдалого бізнесу. Tому good, easy, big money (великі гроші, хороші гроші, які легко заробити) [21]; chief money (фінансовий капітал)[22] володіють суто позитивною конотацією. Змішана конотація присутня у виразі old money (багатство, набуте не в першому поколінні старий капітал) [21]. 3 одного боку, такий капітал $є$ надіним, але ті, хто ним володіють, 
зазвичай відрізняються презирством та пихою щодо пересічних людей із звичайними статками.

Вміння заробити гроші вважається одним з найбільш вдалим, це підтверджується такими Ф0: to make money (заробляти) [22]; there is money in smth. (знатись на інвестуванні, мати з цього гарний/поганий зиск); тоney can be made out of this (на цьому можна заробити) [22]. Цікавим постає семний компонент топеy for jam, for an old rope (легка для виконання та фінансово вигідна робота) [22] з змішаною конотацією, бо у свідомості більшості людей великі гроші пов'язані 3 неабиякими зусиллями, а легкі гроші викликають справедливе занепокоєння. Вони можуть бути blood/danger money (небезпечні, криваві гроші, нажиті нечесним шляхом) [21], а також ними можна заплатити за отримання будь-якої інформації money talks (за гроші можна отримати бідь-яку інформацію) [21]. Їх можуть вливати у сумнівні справи pour/ put/ money into smth (вливати кудись гроші) [21], наприклад, для отримання необхідної думки to get money where one's mouth is - (заробляти гроші та платити за підтримку певної опініiі) to produce or pay money to support one's opinion [22]. Все це викликає емоцію недовіри, остраху на підозрілості.

Не дуже схвальна конотація виявлена у Ф0 money to burn, money affair - (мати багато грошей) [22], або немає куди гроші діти, що, звісно, неправильно та викликає обурення та заздрощі. Інколи гроші йдуть й на добрі справи - raise money for charity (забрати гроші для благодійності) [21], дуже активно вживаний у сучасному мовленні. Не яскраво виражено наступний елемент - «справа» (affair), який транслює наступне значення, пов'язані з бізнесом: financial affair (фінансові справи, відносини) [23]; affiars of state (урядовий бізнес) [22; 23]. Конотація в цілому нейтральна. Присутній компонент non of someone's affair (не лізти в чужу справу) [23], що $є$ найзначущим для англосаксонської свідомості.

Справді великі гроші можна заробити, проводячи торгівлю у великих обсягах та масштабах тому семний компонент «торгівля» (trade) виражено яскраво. ФО do a roaring trade (біти дуже успішним у своєму бізнесі) [23] має позитивну оцінку, з елементами схвалення, особливо якщо підприємець багато працює для бізнесу (doing a brisk trade [21]).

Для неспинного розвитку торгівлі будь-якого рівня важливо шукати клієнтів (ply for trade [22;23]), розширювати сфери впливу. Мати досвід власне бізнесмену та його команді важливо, бо the tricks 
of the trade (тонкощі певної професії, крафту, на якій знаються професіонали) [22] дадуть змогу стрімкого та позитивного зросту торгівлі. Конотація схвальна, з елементами впевненості, захоплення професіоналізмом. В той же час, багато людей хапаються за багато справ одразу, але нічого справді добре зробити не можуть. Це знайшло відбиток у ФО jack of all trades, master of none (майстер на всі руки, але ні в чому не професіонал) [22]. Конотація іронічна, 3 відтінком презирливості. Цікавим $\epsilon$ вираз by trade - (за освітою, фахом) [22], який пов'язаний з фахом в цілому, освітою, а не званнями саме у торгівельній сфері. ФО the rag trade (бізнес з купівлі-продажу одягу) [21] співвідноситься з насамперед жіночим світом моди та виявляється вартим уваги, бо в українській мові таких аналогій не виявлено. Інколи $з$ різних причин власник має cease trading (припинити бізнес через банкрутство) [21]. Це володіє сумною, негативною конотацією незважаючи на причини припинення.

Ще одним з головних напрямів великого бізнесу $є$ промисловість, підприємство (industry), що буде наступним семним компонентом для аналізу. Успішний підприємець, що має компанію 3 великим прибутком, може називатись captain of industry (бізнесмен, що має велику та успішну компанію, підприємство) [22; 23], що дає позитивну конотацію та емотивне забарвлення поваги та захоплення. Схожу конотацію мають вирази industry grows/expands (промисловість росте, розширюється) [21]; a thriving industry (бізнес, що йде дуже добре) [21]. Негативну забарвленість має industry declines (промисловість занепадає). Також є елемент heavy/ light industry (важка/легка промисловість) [21], що має нейтральну конотацію.

Логічною виступає наступна семна складова бізнесу - «угода» (deal). Сам факт купівлі чи продажу тоіварю чи послуги в англійській свідомості зафіксовано як а business deal (коли ви щось купляєте чи продаєте) [21]. Конотація зазвичай нейтральна. Природно, що угода, яка відповідає вимогам та вигідна, є a good deal (гарна угода)[23]; a great deal (шикарна угода) [23]; a done deal (справа узгоджена) [22]. У цьому випадку емотивне забарвлення позитивне, 3 елементами захоплення, задоволення результатом. Особливо останнє підкреслюється такими ФО: to clinch a deal - (погодити угоду до своєї вигоди [21]; to strike a deal - (погодити угоду після багатьох суперечок) [21]. Тут присутній елемент змагання та перемоги, отримання вигоди в найкорисніший себе спосіб. Конотація позитивна.

Зовсім протилежні емоції викликає нечесна угода, 3 незрозумілими умовами та можливим кримінальним підгрунтям. 
Це яскраво ілюструють наступні ФО: a raw deal (нечесна угода); $a$ rough deal (нечесна угода); a shade deal (нелегальна, тіньова угода) [21]. Конотація вкрай негативна, відчутні емоції застереження, небезпеки, тривоги. Заслуговує на увагу ФО (not) big deal (коли людина не вважає факт чи ситуацію важливою) [22], тобто, нічого особливого не сталось. Це значення не дотичне до бізнес-сфери, але лексема «угода» вживається у зафіксованому незвичному контексті.

Яскравою та виразною постає складовою бізнесу «конкуренція» (competition), що відбувається не тільки у бізнесі, але в ньому іiі вживання надзвичайно частотне. Позитивної емоційної забарвленості набуває конкуренція, коли вона відкрита та чесна: open competition (відкрита конкуренція) [21], тоді перебування у конкурентній боротьбі з кимсь (in competition with smb.) [23] може бути успішним, а результат - передбачуваним. Конотація схвальна. Емоція радості та захоплення викликає факт виграшу, перемоги у конкурентній боротьбі: in the face of competition (успішна конкуренція) [21]; win a competition (виграти у конкурентній боротьбі) [21]. Емотивне забарвлення відповідальності має у собі Ф0 run a competition (компанія, що проводить конкурс на щось) [21]; a competition is open to smb. (змагання відкрито)[21]. Конкуренція може бути жорсткою, як й увесь світ великих грошей: stiff, intense competition (жорстка конкуренція) [22], що викликає емоції знервованості, занепокоєння в особистостей тривожного типу та азарт у людей із «спортивним», наполегливим характером.

Семантично до попереднього значення відносяться ФО withdraw of competition (вибити з конкурентної боротьби); knock smb. off competition (вибити з конкурентної боротьби) [21]. Вони викликають емоції роздратування, у тих, хто програв та радість у тих, хто виграв. Тобто, конотація вкрай суперечлива та залежить від ситуації. Але ситуація нечесної конкуренції (unfair competition) [21] викликає емоції обурення та гніву, вкрай негативні.

Зважаючи на вищеописане, в англомовній свідомості лексема «бізнес» у ФО має наступні елементи у своєму складі: «бізнес яг справа»(business); «гроші» (money); «справа»(affair); «торгівля» (trade); «угода» (deal); «дохід» (income), «прибуток» (profit), «конкуренція» (competition), «промисловість», «підприємство» (industry). Конотація в цих складових має неодностайне емоційне забарвлення, а деякі аспекти залежать від контексту, хоча в цілому іiї можна оцінити як позитивну. 


\section{Висновки}

Проведене дослідження семантичної структури лексеми «бізнес» на двох мовних рівнях - лексичному та фразеологічному - виявило основні структурні елементи цього феномену та емотивно-оцінне забарвлення цих складових. Розвідку було виконано на зіставному аналізі двох різносистемних мов - української та англійської для визначення лексико-прагматичних аспектів застосування вищеозначеної лексеми у рекламних CEO-текстах та шаблонах. За результатами було виявлено на лексичному рівні наступні складові: «бізнес як суспільство ділових людей»; «бізнес як підприємство»; «біржа як змістовна частина бізнесу»; біржові операції та професії»; «бізнес як комерційна діяльність»; «бізнес-галузі у різних сферах життєдіяльності»; «бізнес як справа у широкому сенсі».

Загалом, лексема «бізнес» має нейтрально-позитивне значення у проаналізованих прикладах на лексичному рівні. В англійській мові виявлено наступне розподілення семних компонентів: «бізнес як підприємництво»; «бізнес як своя (сімейна) справа»; «бізнес як джерело прибутку»; «бізнес як торгівля»; «бізнес як благодійність» (таке значення відсутнє в українських джерелах); «бізнес як покликання»; «бізнес як комерція»; специфічний компонент «бізнес як театральний прийом». Конотацію можна схарактеризувати як позитивно-нейтральну. Специфічними є суто англійські «бізнес як благодійність» та «бізнес для театральний прийом».

Треба підкреслити, що для української реальності ця лексема $\epsilon$ значно більш новою, бо увійшла у розмовне вживання з 80х років XXго століття, тоді як для британської мовної культури «бізнес» існував $3 \mathrm{XV}$ сторіччя. Але у головному $є$ й тотожність, бо лексема запозичена саме з англійської мови - це складова «бізнес як джерело прибутку».

На фразеологічному рівні, де досліджувалось переважно емотивно-прагматична функція лексеми «бізнес», проаналізовано наступні складові в українській мові: «лідерство», «високий дохід», бінарна опозиція «чесність/нечесність», бінарна опозиція «працьовитість/лінощі», «ентузіазм», «професіоналізм», «статусність», бінарна опозиція «удача/невдача», «корисливість», «амбітність», «досвід», «авторитарність». Конотація у багатьох випадках має різноманітні відтінки значення та не може храктеризуватись як суто позитивна чи негативна.

Аналіз ФО на основі англомовних автентичних джерел виявив такі складові: бізнес як «справа» (business); «гроші» (money); «справа»(affair); «торгівля» (trade); «угода» (deal); «дохід» (income), 
«прибуток» (profit), «конкуренція» (competition), «промисловість», «підприємство» (industry).

Конотація в цих складових має неоднорідну забарвленість, а деякі аспекти залежать від контексту, тому можуть значно змінюватись. Але наявна тенденція до позитивного емотивного забарвлення лексеми «бізнес» у складі як українських, так й англомовних $Ф 0$. Тему впливу конотації на написання успішних та ефективних рекламних текстів плануємо продовжувати у подальших дослідженнях з цієї проблематики.

\section{Список використаних джерел:}

1. Англо-український та українсько-англійський словник. / В. І. Перебийніс, Е.П. Рукіна, І.В. Тименко, С.С. Хідекель. Харків: «Фоліо», 2007. 368 с.

2. Вежбицкая А. Семантические универсалии и описание языков. Москва: Яз. рус. культуры, 1999. 780 с.

3. Великий тлумачний словник сучасної української мови : 250000 / уклад. та голов. ред. В. Т. Бусела. Київ; Ірпінь: Перун, 2005. 1728 с.

4. Зубков М., Мюллер В. Сучасний англо-український та українсько-англійський словник. Харків: ВД «Школа», 2007. 768 с.

5. Івченко А.О. Тлумачний словник української мови. Харків: Фоліо, 2000. 540 c.

6. Калашник В.С., Колоїз Ж.В. Словник фразеологічних антонімів української мови. Київ: Довіра, 2004. 284 с.

7. Крюков И.А. Концепт «бизнес» в концептосфере русского языка последних лет. (на материале национального корпуса русского языка). Лингвистика. Вестник Нижегородского университета им. Н.И. Лобачевского 2009. № 6. С. 266-269.

8. Олійник І.С., Сидоренко М. М. Україно-російський і російськоукраїнський фразеологічний словник. Київ: Рад. школа, 1978. 446 с.

9. Попова З.Д., Стернин И.А. Очерки по когнитивной лингвистике. Изд-во Воронеж, 2003. 238 с.

10. Російсько-український тлумачний словник для ділових людей / Тараненко 0.0., Брицин В. М., за ред. О.О. Тараненка. Київ: Укр. Письменник, 1992. 214 с.

11. Селіванова 0. О. Актуальні напрями сучасної лінгвістики. Київ: Вид-во Фітосоціоцентр. 1999. 148 с.

12. Словник української мови. / Під ред. І. К. Білодіда. Київ: Наукова думка. 1970-1980 р.p. Т. 1. 541 с. 
13. Сучасний тлумачний словник української мови: 100.000 слів/за ред. проф. В. В. Дубічинського. Харків: ВД «Школа», 2009. $1008 \mathrm{c}$.

14. Тлумачний словник-мінімум української мови. 9.000 слів. уклад. Л.О. Ващенко, О.М. Єфімов. «Довіра», 2004. 238 с.

15. Тлумачний словник чужомовних слів в українській мові. Уклад. О.М. Сліпушко, Київ: «Криниця», 1999. 508 с.

16. Українсько-англійський словник. Економіка. Фінанси. Банки. Інвестиції. Кредити./ Уклад. С.Я. Єрмоленко, В.І. Єрмоленко Київ: «Школа», 2003. 568 с.

17. Фразеологічний словник української мови. Під ред. В.М. Білоноженко. Київ: «Наукова думка», 2005. 954 с.

18. Яковлева А.М., Афонська Т.М. Сучасний тлумачний словник української мови. Харків: ТОРСІНГ ПЛЮС, 2006. 672 с.

19. Dictionary.com. Thesaurus.com. Dictionary.com LCC, 2021 URL: https://www.dictionary.com/browse/business (дата звернення: 22.10.2021)

20. Investopedia. Business. Business Essentials. By Adam Hayes. 2021. URL: https://www.investopedia.com/terms/b/business.asp (дата звернення: 22.10.2021)

21. Longman Dictionary of Contemporary English. Pearson. URL: https://www.ldoceonline.com/dictionary/business. (дата звернення: 22.10.2021)

22. Oxford Learners Dictionary. Oxford University Press, 2021 URL: https://www.oxfordlearnersdictionaries.com/definition/english/busin ess?q=business (дата звернення: 22.10.2021)

23. Meriam Webster Dictionary since 1828. Thesaurus. URL: $\quad$ https://www.merriam-webster.com/dictionary/business (дата звернення: 22.10.2021) 